University of Nebraska - Lincoln

DigitalCommons@University of Nebraska - Lincoln

U.S. National Park Service Publications and

Papers

National Park Service

$12-19-2019$

Direct and indirect effects of temperature and prey abundance on bald eagle reproductive dynamics

Joshua H. Schmidt

Judy Putera

Tammy L. Wilson

Follow this and additional works at: https://digitalcommons.unl.edu/natlpark

Part of the Environmental Education Commons, Environmental Policy Commons, Environmental

Studies Commons, Fire Science and Firefighting Commons, Leisure Studies Commons, Natural Resource

Economics Commons, Natural Resources Management and Policy Commons, Nature and Society

Relations Commons, Other Environmental Sciences Commons, Physical and Environmental Geography

Commons, Public Administration Commons, and the Recreation, Parks and Tourism Administration

Commons

This Article is brought to you for free and open access by the National Park Service at DigitalCommons@University of Nebraska - Lincoln. It has been accepted for inclusion in U.S. National Park Service Publications and Papers by an authorized administrator of DigitalCommons@University of Nebraska - Lincoln. 


\title{
Direct and indirect effects of temperature and prey abundance on bald eagle reproductive dynamics
}

\author{
Joshua H. Schmidt ${ }^{1}$ (i) $\cdot$ Judy Putera ${ }^{2} \cdot$ Tammy L. Wilson $^{3,4}$ \\ Received: 23 April 2019 / Accepted: 5 December 2019 / Published online: 19 December 2019 \\ (c) This is a U.S. Government work and not under copyright protection in the US; foreign copyright protection may apply 2019
}

\begin{abstract}
Understanding the mechanisms by which populations are regulated is critical for predicting the effects of large-scale perturbations. While discrete mortality events provide clear evidence of direct impacts, indirect pathways are more difficult to assess but may play important roles in population and ecosystem dynamics. Here, we use multi-state occupancy models to analyze a long-term dataset on nesting bald eagles in south-central Alaska with the goal of identifying both direct and indirect mechanisms influencing reproductive output in this apex predator. We found that the probabilities of both nest occupancy and success were higher in the portion of the study area where water turbidity was low, supporting the hypothesis that access to aquatic prey is a critical factor limiting the reproductive output of eagles in this system. As expected, nest success was also positively related to salmon abundance; however, the negative effect of spring warmth suggested that access to salmon resources is indirectly diminished in warm springs as a consequence of increased glacial melt. Together, these findings reveal complex interrelationships between a critical prey resource and large-scale weather and climate processes which likely alter the accessibility of resources rather than directly affecting resource abundance. While important for understanding bald eagle reproductive dynamics in this system specifically, our results have broader implications that suggest complex interrelationships among system components.
\end{abstract}

Keywords Bottom-up $\cdot$ Food limitation $\cdot$ Multi-state $\cdot$ Population dynamics $\cdot$ Weather

\section{Introduction}

There is a growing body of evidence that bottom-up forces are important drivers of abundance (Frederiksen et al. 2006; Schmidt et al. 2018b) and reproductive output (Schmidt et al. 2018a) in many natural systems. The primary bottomup mechanism affecting population dynamics is access to

Communicated by Mathew Samuel Crowther.

Joshua H. Schmidt

joshua_schmidt@nps.gov

1 Central Alaska Network, U.S. National Park Service, 4175 Geist Road, Fairbanks, AK 99709, USA

2 Wrangell St. Elias National Park and Preserve, U.S. National Park Service, PO Box 439, Copper Center, AK 99573, USA

3 Southwest Alaska Network, U.S. National Park Service, 240 W. 5th Avenue, Anchorage, AK 99501, USA

4 Present Address: Department of Natural Resource Management, South Dakota State University, 1390 College Ave, Box 2140B, Brookings, SD 57007, USA food (e.g., White 2008; Parker et al. 2009), the effects of which have been demonstrated through supplemental feeding experiments in a variety of bird species (Brittingham and Temple 1988; Gill et al. 2002; Preston and Rotenberry 2006). Food limitation can be mediated by a variety of factors including territoriality, social dynamics, movement, and reductions in fecundity (Wallach et al. 2015), although their importance varies among species and systems.

Variation in weather and climate influence primary productivity and are important drivers of population dynamics in a variety of vertebrate taxa including ungulates (Post and Stenseth 1999; Rattenbury et al. 2018), passerines (Sillett et al. 2000; Boelman et al. 2017), seabirds (Thompson and Ollason 2001), and raptors (Franklin et al. 2000; Fairhurst and Bechard 2005; Glenn et al. 2010). The effects of weather and climate can be both direct and indirect, potentially complicating a mechanistic understanding of systems. Mortalities related to extreme events are a commonly observed example of direct impacts of variable weather conditions (Parmesan et al. 2000; Anctil et al. 2014), while indirect impacts are more subtle and can be manifest as variation in 
resource abundance or availability that in turn affects vital rates (e.g., Durant et al. 2007; White 2008; Dybala et al. 2013; Schmidt et al. 2018a, b). Identifying the effects of variation in weather and climate on vertebrate taxa and their prey is critical for our collective understanding of how future changes in weather patterns may affect populations.

In coastally connected systems in the north, salmon often represent a large potential prey resource for a variety of consumers (Buehler 2000; Gende et al. 2004; Hilderbrand et al. 2004) and transport large quantities of marine-derived nutrients into terrestrial ecosystems (Helfield and Naiman 2006). However, salmon abundance can be impacted by climate variation through changes in survival rates (Finney et al. 2000; Mueter et al. 2002; Farley et al. 2011). During migration, river discharge rates can also influence the ability of salmon to reach the spawning grounds (Rand et al. 2006; Martins et al. 2012), and high flow-rates caused by melting snow and ice can delay the timing of in-river salmon migration (Hodgson et al. 2006; Keefer et al. 2007). These findings imply that drivers of salmon returns could have bottom-up impacts on terrestrial predators that rely on salmon returns as a primary food resource.

The tendency of raptors to reuse nesting sites makes them a convenient focal group for studying dynamics in predator-prey systems (e.g., Korpimaki 1992; Wiehn and Korpimaki 1997; McIntyre and Schmidt 2012). Research on bald eagles has shown that population dynamics are influenced in part by food availability (Hansen 1987; Gende and Willson 1997; Elliot et al. 1998; Hoff et al. 2004) and weather conditions through both direct and indirect means (Steidl et al.1997; Gende et al. 1997; Swenson et al. 1986). Bald eagle reproductive dynamics are often assessed at the level of individual nests which can be revisited annually to compile metrics such as nest occupancy, success, and productivity (Watts and Duerr 2010; Wilson et al. 2014; Cruz et al. 2018). Often, summary statistics such as the proportion of successful nests, or the average number of young produced per occupied nest are calculated and used for inference (e.g., Zwiefelhofer 2007). While such approaches are useful, they can be analytically inefficient, potentially limiting assessments of factors influencing reproductive parameters. Occupancy models have become a powerful tool for assessing site dynamics in unmarked populations (MacKenzie et al. 2003, 2018) and have been widely applied in raptor monitoring and research (e.g., Sergio and Newton 2003; McIntyre and Schmidt 2012). When multiple possible occupancy states are of interest (e.g., unoccupied, occupied without reproduction, occupied with successful reproduction), a multi-state occupancy framework can provide additional insights into population dynamics (Nichols et al. 2007; MacKenzie et al. 2012, 2018). These approaches have recently been implemented more widely for the study of raptor populations (Martin et al. 2009; Wilson et al. 2014, 2018; Mizel et al. 2018) providing additional insights into reproductive ecology. We expected that a multi-state occupancy framework would be useful in assessing the roles of weather and food resources in bald eagle reproductive dynamics.

Here, we used a multi-season multi-state occupancy modeling framework to investigate spatial and temporal variation in bald eagle nest occupancy state in relation to the interplay between spring weather conditions and run strength of salmon (Oncorhynchus spp.) in the Copper River drainage in south-central Alaska, USA from 2004 to 2018. This system is useful for evaluating the effects of food availability and weather events on bald eagle demographic parameters because forage is dominated by salmon, thereby providing a good opportunity to evaluate patterns with relatively few confounding effects. Our primary objectives were to: (1) assess broad spatial patterns in nest occupancy state throughout our study area, and (2) assess the role of spring temperatures and early season salmon run strength on bald eagle nest occupancy state. We hypothesized that early salmon run strength would be positively related to bald eagle nest occupancy state, while warm springs would result in decreased probabilities of occurring in a higher occupancy state due to reduced food availability as a consequence of increased stream flow in this glacially fed system. Meeting these objectives would provide insights into the reproductive dynamics of bald eagles and identify how indirect pathways can impact on ecosystems.

\section{Materials and methods}

\section{Study area}

Our study area included the riparian corridor along most of the Copper River, as well as two major tributaries, the Chitina and Bremner Rivers (Fig. 1). We divided the overall study area into 5 survey subareas, largely defined by Kozie (1996). The Upper Copper River subarea includes $80 \mathrm{~km}$ of the Copper River upstream of the Chistochina River, as well as Tanada Creek and Copper and Tanada lakes. The Middle Copper River subarea $(179 \mathrm{~km})$ extends from the Chistochina River south to the confluence with the Chitina River. The Lower Copper River subarea $(188 \mathrm{~km})$ extends from the Chitina River south to Miles Lake. The Chitina River subarea extends $116 \mathrm{~km}$ of the Chitina River upstream from the Copper River confluence. The Bremner subarea extends $45 \mathrm{~km}$ from the Copper River confluence upstream to Threemile Canyon. Most of the Copper River drainage is glacial in origin, draining $68,600 \mathrm{~km}^{2}$ including much of the south side of Wrangel-St. Elias National Park and Preserve. As many as 1.2 million sockeye salmon (Oncorhynchus nerka) return to the Copper River each year, providing a large food resource for bald eagles. The Copper, 


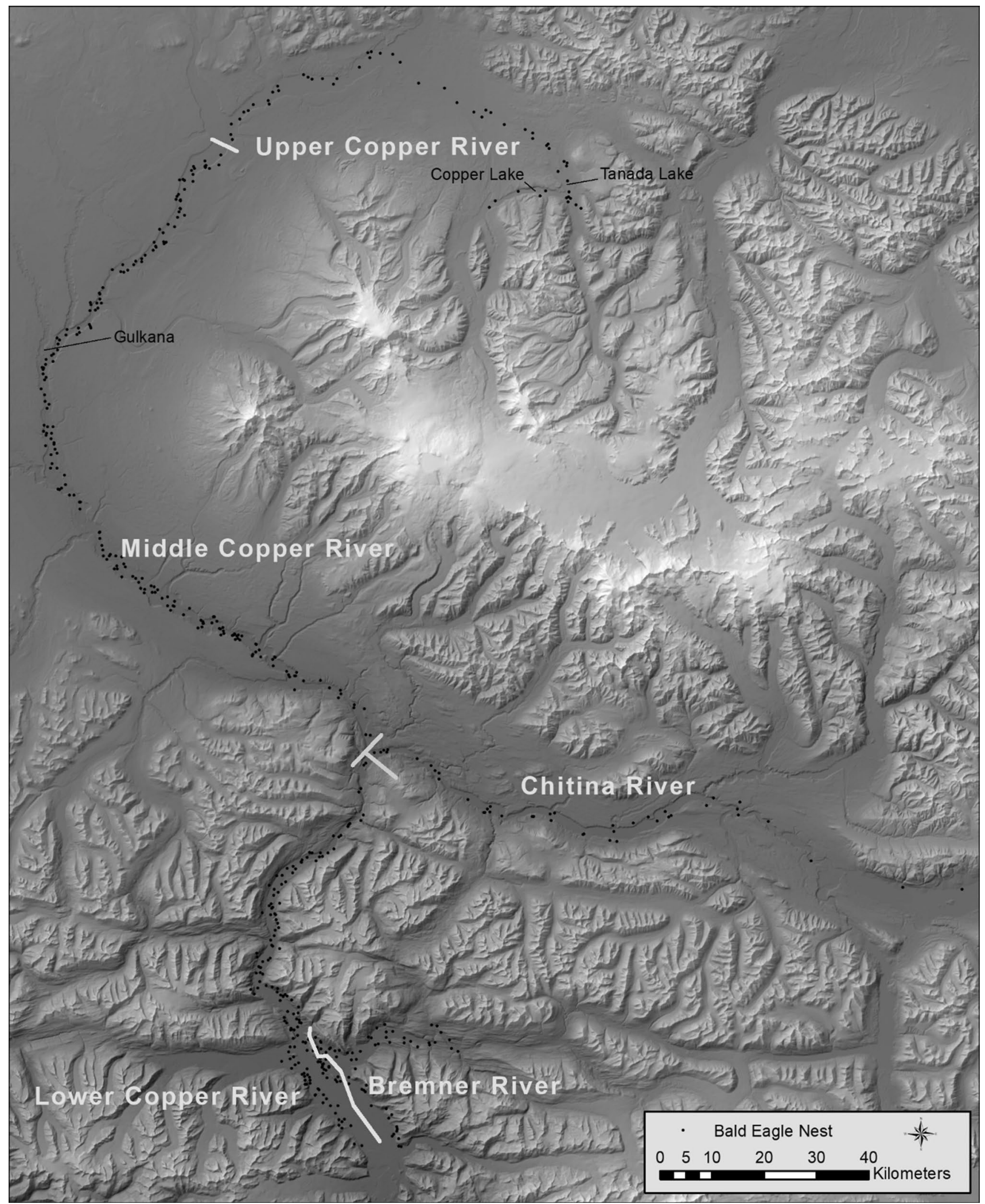

Fig. 1 Map of the bald eagle study area in south-central Alaska, USA showing nest distribution along the Copper, Chitina, and Bremner rivers. The 5 survey subareas are also shown. We added random spatial noise to protect actual nest locations 
Chitina, and Bremner rivers are glacial, meaning that they have high silt loads, high turbidity, and flows that are driven in part by temperature which determines runoff from snow and ice melt. The primary exception is the Tanada Creek and Copper and Tanada Lakes portion of the Upper Copper River subarea which is non-glacial and, therefore, has clear water. The riparian zone along these rivers represents the primary nesting habitat for bald eagles, typically dominated by white spruce (Picea glauca) in the north, with balsam popular (Populus balsamifera) becoming common in the south. In the Lower Copper River and Bremner River subareas, black cottonwood (Populus trichocarpa), Sitka spruce (Picea sitchensis), and mountain hemlock (Tsuga mertensiana) are also present.

\section{Field methods}

We conducted two surveys annually, a nest occupancy survey in mid-May at which point all nests were assumed to have been initiated, and a productivity survey in late-July to early-August prior to the fledging period to determine nest success. We conducted each survey using a tandem fixedwing aircraft (e.g., Piper Supercub; Piper Aircraft, Inc., Vero Beach, FL) flown at $<100 \mathrm{~m}$ above the ground. Known nest locations were input into the pilot's GPS to facilitate an efficient search pattern. During the May occupancy survey, the pilot-observer team searched all bald eagle habitat within the riparian corridor for nests, while systematically revisiting all known nest locations. The narrow riparian corridor generally allowed adequate coverage from a single pass on either side of the river, although multiple passes were made when needed to cover all riparian habitats. When a new nest was detected, the characteristics (e.g., tree species, nest condition) and spatial location were recorded to facilitate relocation in subsequent surveys. During the occupancy survey, each detected nest was classified as occupied if it contained eggs, an adult eagle in an incubating posture, or if 2 adults were perched on or near the nest tree. Otherwise the nest was deemed to be unoccupied. If an individual nest was not found for $>2$ years, it was assumed to have been destroyed (e.g., nest tree fell over) and removed from the list of known nests. We used the nest as the sample unit rather than the nesting territory, as has been done in past studies (e.g., Gende et al. 1997; Anthony et al. 2008), to avoid subjective decisions regarding territory assignment. During the productivity survey, the pilot-observer team only revisited nests that had been classified as occupied during the earlier occupancy survey. Revisited nests were reclassified as occupied but unsuccessful (no chick present), successful (1 chick present), or highly successful ( $>1$ chick present). Over the course of the study, only two instances of three chick broods were observed; therefore, highly successful nests essentially produced two chicks. While the pilot-observer team did not actively search for nests during the productivity survey, previously undiscovered nests were occasionally found. When this occurred, the new nests were added to the list as during the occupancy survey, but if no chicks were present, the occupancy state was assumed to be unknown because there was no way to know if the nest had been occupied but then failed prior to the second survey. We acknowledge that a single survey during each period likely resulted in state misclassification errors (i.e., Wilson et al. 2017), although we expect these to be limited because bald eagles tend to have high nest attendance rates during the incubation period (Buehler 2000). Any errors would also most likely increase variation in our data, thereby decreasing our ability to detect covariate effects rather than leading to spurious results.

\section{Analytical methods}

We used a multi-season multi-state occupancy modeling framework for analysis. Because we were primarily interested in occupancy patterns through time and our dataset did not consistently include the same nests (i.e., nests were added and lost from the population continuously, incomplete surveys in some years), we used an implicit dynamics formulation (MacKenzie et al. 2018). The basic model had four possible occupancy states for each nest: unoccupied, occupied, successful, and highly successful. Following the notation of Kéry and Schaub (2012), the probability of the state, $z$, of nest $i$ in year $j$ is modeled using a categorical distribution

$z_{i j} \sim \operatorname{categorical}\left(\boldsymbol{\Omega}_{i j}\right)$,

where $\boldsymbol{\Omega}_{i j}$ is the state vector. Using the following parameterization

$\boldsymbol{\Omega}_{i j}=\left[\begin{array}{c}1-\Psi_{1, i j} \\ \Psi_{1, i j}\left(1-\Psi_{2, i j}\right) \\ \Psi_{1, i j} \Psi_{2, i j}\left(1-\Psi_{3, i j}\right) \\ \Psi_{1, i j} \Psi_{2, i j} \Psi_{3, i j}\end{array}\right]$,

where $\Psi_{1}$ is the probability a given nest is occupied, $\Psi_{2}$ is the probability that successful reproduction occurs at an occupied nest, $\Psi_{3}$ is the probability that a successful nest is highly successful, and $1-\Psi_{1, i j}$ is the probability that a nest is unoccupied. The observed states, $y_{i j}$, come from a categorical distribution

$y_{i j} \sim \operatorname{categorical}\left(\boldsymbol{\Theta}_{1 \ldots O, i, k}\right)$,

where $\Theta$ is the observation array, $O$ is the total number of states, and $k$ indicates the visit. Because the two visits to each nest in our study occurred during different portions of the breeding season, $\boldsymbol{\Theta}$ is 
unoccupied occupied 1 chick $>1$ chick

unoccupied
occupied
successful
highly successful $\left[\begin{array}{llll}1 & 0 & 0 & 0 \\ 0 & 1 & 0 & 0 \\ 0 & 1 & 0 & 0 \\ 0 & 1 & 0 & 0\end{array}\right]$

for $k=1$ and unoccupied occupied 1 chick $>1$ chick

unoccupied
occupied
successful
highly successful $\left[\begin{array}{llll}1 & 0 & 0 & 0 \\ 0 & 1 & 0 & 0 \\ 0 & 0 & 1 & 0 \\ 0 & 0 & 0 & 1\end{array}\right]$

for $k=2$. The first survey occurs prior to hatch; therefore, the successful and highly successful states are not yet observable. During the second survey, the true state is assumed to be observed without error. The observation matrix for $k=1$ is generally only relevant when a given nest is not observed during the second survey, thereby acknowledging the potential for state classification error.

Under the implicit dynamics model formulation, we can also consider the effects of covariates on each state

$\operatorname{logit}\left(\Psi_{1, i j}\right)=x_{i j}^{\prime} \alpha$,

$\operatorname{logit}\left(\Psi_{2, i j}\right)=x_{i j}^{\prime} \beta$

$\operatorname{logit}\left(\Psi_{3, i j}\right)=x_{i j}^{\prime} \gamma$,

where $x_{\mathrm{j}}$ is a vector of covariates and $\boldsymbol{\alpha}, \boldsymbol{\beta}$, and $\boldsymbol{\gamma}$, are the associated coefficients. For our analysis, the covariates we considered were: subarea, annual trend through time, annual cumulative maximum growing degree days (GDD) prior to June 1, annual number of salmon entering the Copper River prior to June 1, and an interaction between GDD and salmon numbers. Salmon numbers include a relatively small number (generally $<5 \%$ ) of Chinook salmon (Oncorhynchus tshaw$y t s c h a$ ), although the large majority are sockeye salmon. We assumed using the spring period prior to June 1 would capture warmth and salmon abundance most likely to influence the critical incubation and early nestling periods. We used GDD as an index of snow and ice melt in this glacial system because complete stream gauge data were not available. We acquired temperature data from the Gulkana weather station located immediately adjacent to the Middle Copper subarea (Fig. 1) and calculated GDD from April 1-May 31. Although the Gulkana station is the only first-order weather station adjacent to our study area, we expected it to be a reasonable measure of broad weather conditions during our study (Shulski and Wendler 2007). The number of salmon entering the river was recorded at the Miles Lake sonar site operated by the Alaska Department of Fish and Game at the southern terminus of our study area (see Mejjati et al. 2010). We scaled the GDD and salmon covariates to have a mean $=0$ and $\mathrm{SD}=1$ prior to analysis to improve convergence. We fit our model using program R 3.1.1 (R Development Core Team 2014) and OpenBUGS (Thomas et al. 2006) using a Bayesian approach. We used uninformative priors on all parameters and ran two independent Markov chains for 20,000 iterations each, discarding the initial 10,000 as burn-in, retaining the rest for inference. We used a visual inspection of the chains and the Gelman-Rubin diagnostic (Brooks and Gelman 1998) to assess convergence. We used the 95\% Bayesian credible intervals to determine which covariates had interpretable impacts on each occupancy state (i.e., those that did not overlap 0).

\section{Results}

After the initial 2 years of the project, during which surveys were largely limited to the Middle and Lower Copper subareas, 271-321 nests were surveyed annually throughout the study area (Table 1, Fig. 1). The only exception was 2010 when a lack of funding precluded all surveys. Our measure of spring warmth, GDD prior to June 1, varied almost twofold from 439 to 855 . The size of the spring salmon run was much more variable, ranging from 26,654 to 415,831 fish passing the Miles Lake sonar site at the southern terminus of our study area each year prior to June 1 (Table 1).

We found no evidence that the probability of a nest being occupied was related to spring temperatures or salmon run 
strength (Table 2), although we anticipated that the impact of salmon abundance on nest occupancy may be minor because salmon would only be available to nesting eagles for a short period prior to the occupancy survey. However, nests in the Upper Copper subarea (where clear water habitats were present) were substantially more likely to be occupied than nests in the other 4 subareas (Tables 2, 3). In addition, the probability that an occupied nest was successful within a given year was lower in warmer springs and higher in years with strong early salmon runs (Table 2, Fig. 2a), consistent with our predictions. The relative effect sizes were similar indicating that a $-1 \mathrm{SD}$ change in GDD had approximately the same effect size as a $+1 \mathrm{SD}$ change in salmon run strength (see Fig. 2b, c). In addition, the negative interaction between GDD and salmon abundance indicated that there was a curvilinear relationship between these two variables and the probability of a nest being successful (Fig. 2a). The only apparent temporal trend was an increase in the probability that a nest was successful over time (Fig. 3). As was the case for occupancy, nests in the Upper Copper subarea were also more likely to be successful than the other 4 subareas (Table 2, Fig. 2). While the probability of a nest being highly successful was not linearly related to either spring warmth or salmon run strength, there was support for a negative interaction between them, resulting again in a curvilinear relationship which showed that, given that a

Table 1 Annual number of bald eagle nests sampled within the Copper River drainage in south-central Alaska, USA 2004-2018

\begin{tabular}{lllc}
\hline Year & Nests sampled & Spring GDD & $\begin{array}{c}\text { Early salmon } \\
\text { run strength }\end{array}$ \\
\hline 2004 & 86 & 754 & 188,576 \\
2005 & 152 & 800 & 201,739 \\
2006 & 274 & 577 & 122,640 \\
2007 & 321 & 653 & 116,871 \\
2008 & 319 & 624 & 95,406 \\
2009 & 307 & 693 & 167,425 \\
2010 & - & 735 & 94,757 \\
2011 & 291 & 662 & 260,339 \\
2012 & 289 & 648 & 415,831 \\
2013 & 278 & 439 & 26,654 \\
2014 & 278 & 744 & 308,309 \\
2015 & 271 & 800 & 328,174 \\
2016 & 280 & 855 & 181,663 \\
2017 & 285 & 714 & 166,114 \\
2018 & 276 & 589 & 39,122 \\
\hline
\end{tabular}

Corresponding values of spring warmth as measured by accumulated growing degree days (GDD) prior to June 1, and the number of salmon passing the Miles Lake sonar site prior to June 1 (early salmon run strength) are also included. Surveys were largely restricted to the Middle and Lower Copper subareas in 2004-2005, and surveys were not conducted in 2010
Table 2 Parameter estimates (logit-scale) with standard deviation (SD) and lower and upper 95\% credible intervals

\begin{tabular}{|c|c|c|c|c|}
\hline Parameter & Mean & SD & $2.5 \%$ & $97.5 \%$ \\
\hline Upper.int $_{1}$ & 0.07 & 0.13 & -0.19 & 0.34 \\
\hline Middle.int $_{1}$ & -0.52 & 0.09 & -0.69 & -0.35 \\
\hline Lower.int $_{1}$ & -0.70 & 0.10 & -0.89 & -0.50 \\
\hline Chitina.int $_{1}$ & -0.70 & 0.15 & -0.98 & -0.41 \\
\hline Bremner.int $_{1}$ & -0.61 & 0.13 & -0.86 & -0.36 \\
\hline Upper.int $_{2}$ & 0.83 & 0.22 & 0.45 & 1.28 \\
\hline Middle.int $_{2}$ & -0.69 & 0.16 & -0.98 & -0.38 \\
\hline Lower.int $_{2}$ & -0.33 & 0.17 & -0.66 & 0.01 \\
\hline Chitina.int $_{2}$ & -1.66 & 0.31 & -2.26 & -1.07 \\
\hline Bremner.int $_{2}$ & -0.93 & 0.24 & -1.37 & -0.48 \\
\hline Upper.int $_{3}$ & -0.26 & 0.27 & -0.77 & 0.25 \\
\hline Middle.int $_{3}$ & -0.11 & 0.24 & -0.58 & 0.36 \\
\hline Lower.int $_{3}$ & -0.48 & 0.26 & -0.98 & 0.03 \\
\hline Chitina.int $_{3}$ & -0.22 & 0.51 & -1.22 & 0.76 \\
\hline Bremner.int $_{3}$ & -0.56 & 0.37 & -1.27 & 0.17 \\
\hline trend $_{1}$ & 0.00 & 0.01 & -0.02 & 0.02 \\
\hline $\operatorname{trend}_{2}$ & 0.05 & 0.02 & 0.01 & 0.08 \\
\hline trend & 0.01 & 0.02 & -0.04 & 0.05 \\
\hline $\mathrm{GDD}_{1}$ & 0.05 & 0.05 & -0.04 & 0.14 \\
\hline $\mathrm{GDD}_{2}$ & -0.21 & 0.08 & -0.37 & -0.04 \\
\hline $\mathrm{GDD}_{3}$ & 0.02 & 0.12 & -0.21 & 0.26 \\
\hline Salmon $_{1}$ & 0.03 & 0.04 & -0.06 & 0.11 \\
\hline Salmon $_{2}$ & 0.18 & 0.07 & 0.04 & 0.32 \\
\hline Salmon $_{3}$ & -0.06 & 0.10 & -0.25 & 0.13 \\
\hline $\mathrm{GDD}_{1}{ }^{*}$ salmon $_{1}$ & 0.06 & 0.05 & -0.04 & 0.14 \\
\hline $\mathrm{GDD}_{2} *$ salmon $_{2}$ & -0.18 & 0.08 & -0.33 & -0.03 \\
\hline $\mathrm{GDD}_{3}{ }^{*}$ salmon $_{3}$ & -0.34 & 0.12 & -0.56 & -0.12 \\
\hline
\end{tabular}

Each int represents the intercept for each of the 5 survey subareas, GDD is cumulative growing degree days prior to June 1, and salmon is the total number of salmon passing the Miles Lake sonar in May. Subscripts indicate covariate effects on the probability of a nest being occupied (1), successful (2), or highly successful (3). Note that covariates GDD and salmon have been scaled to have mean $=0$ and $\mathrm{SD}=1$

nest was successful, the probability of it also being highly successful was lowest under average conditions (Table 2, Fig. 2d). Although there were no differences in the probability of an occupied nest being highly successful among subareas, highly successful nests were more likely in the Upper Copper subarea due to higher probabilities of both occupancy and success there (Table 2, Fig. 2d).

For comparison with past work, we also derived average estimates of success and productivity (i.e., average number of chicks produced) over our entire study period. The average probability of success for an occupied nest was 0.46 [95\% CrI 0.43-0.48]. Productivity averaged 0.64 [95\% CrI 0.61-0.68] for occupied nests and 1.4 [95\% CrI 1.37-1.44] for successful nests. Average probabilities of occupancy and success were both higher in the Upper Copper subarea as 
Table 3 Estimated average probabilities by subarea of a nest being occupied, successful given occupancy, and highly successful given it was successful

\begin{tabular}{llll}
\hline & Mean & $2.5 \%$ & $97.5 \%$ \\
\hline Occupancy & & & \\
Upper & 0.52 & 0.47 & 0.57 \\
Middle & 0.37 & 0.35 & 0.40 \\
Lower & 0.33 & 0.30 & 0.36 \\
Chitina & 0.33 & 0.28 & 0.39 \\
Bremner & 0.35 & 0.31 & 0.40 \\
Successful & & & \\
Upper & 0.75 & 0.68 & 0.81 \\
Middle & 0.40 & 0.36 & 0.44 \\
Lower & 0.48 & 0.43 & 0.54 \\
Chitina & 0.21 & 0.13 & 0.30 \\
Bremner & 0.35 & 0.27 & 0.43 \\
Highly successful & & & \\
Upper & 0.41 & 0.33 & 0.50 \\
Middle & 0.45 & 0.38 & 0.52 \\
Lower & 0.36 & 0.29 & 0.44 \\
Chitina & 0.43 & 0.22 & 0.65 \\
Bremner & 0.35 & 0.22 & 0.49 \\
\hline
\end{tabular}

compared to the remainder of the study area, while the probability of an occupied nest being successful was significantly lower in the Chitina subarea (Table 3). The probability of a nest being highly successful, given that it was occupied and successful, was similar throughout the study area (Table 3).

\section{Discussion}

We found that eagle nest success was associated with the interacting direct and indirect effects of spring GDD and salmon abundance. While direct positive impacts of salmon abundance were expected, spring warmth appeared to have a countervailing effect, suggesting a complex relationship between weather conditions and food availability in this glacially fed system. While the direct effects of lower GDD could theoretically decrease productivity, our results suggest that any negative impacts may be outweighed by the positive effects of increased access to salmon resources. These findings suggest that identifying the mechanisms underlying relationships between population dynamics, food resources, and weather conditions could be important for predicting the future impacts of a changing climate on wildlife populations. Although these findings inform our understanding of potential drivers of bald eagle population dynamics in the Copper River drainage specifically, they also demonstrate more broadly how complex interactions between weather conditions and food resources can affect natural systems through alternative bottom-up pathways.

It is well established that limited food resources can negatively affect reproductive dynamics in bald eagles (Hansen 1987; Elliot et al. 1998, 2011; Hoff et al. 2004; Rubenstein et al. 2019) and other raptors (Korpimaki 1992; Wiehn and Korpimaki 1997; Byholm et al. 2007; McIntyre and Schmidt 2012). Despite a sizable salmon resource, bald eagle productivity in the Copper River drainage is generally low in comparison with other areas (Ritchie and Ambrose 1996; Steidl et al. 1997; Wilson et al. 2018), presumably due to river turbidity which limits salmon availability (i.e., visibility) to bald eagles (Steidl et al. 1997). This hypothesis was supported by our observation of substantially higher probabilities of bald eagle nest occupancy and success in the Upper Copper subarea where clear water streams and spawning lakes are present. Generally, higher success in the adjacent clear water Gulkana River drainage (Steidl et al. 1997) provides further evidence that access to salmon is an important factor limiting the reproductive output of nesting bald eagles in this system.

Although water clarity may explain broad geographic patterns of bald eagle nest occupancy and success that we observed on the Copper River, we found that the expected positive relationship between the strength of the salmon run interacted with a negative effect of spring GDD. Although the direct effects of GDD may be expected to be positive, we hypothesized that warm springs might accelerate or exacerbate spring runoff and thus have an indirect negative effect on bald eagle nest occupancy and success by further reducing access to salmon resources (Hansen 1987). Discharge and turbulence are known to affect salmon migration efficiency (Hinch and Rand 1998), and impact the ability of salmon to reach spawning areas, especially if the physiological capacities of spawning fish are exceeded (Bernatchez and Dodson 1987; Rand et al. 2006). Further, the availability of salmon to eagles can be influenced by the presence of gravel bars and shallow water habitats that allow eagles to access salmon carcasses during the early nesting period (Hansen 1987; Rubenstein et al. 2019). We, therefore, concluded that salmon availability was likely reduced in years with high spring GDD due to increased glacial melt, thereby affecting nest success.

Warm temperatures are often associated with increased reproductive output in raptors living in cold climates (e.g., Fairhurst and Bechard 2005; Väli 2012), including bald eagles (Mougeot et al. 2013; Wilson et al. 2018). Warmth could directly improve chick production by alleviating the energetic demands of adults (Stalmaster and Gesssaman 1984; Harvey et al. 2012; Redpath et al. 2002), while harsh temperatures and inclement weather early in the nesting period can lead to nest failure (Gende et al. 1997; Rodríguez and Bustamante 2003). In contrast to the general pattern 
Fig. 2 Plots showing the probability of occurring in a particular occupancy state in relation to growing degree days (GDD) and salmon abundance in each of the 5 major river segments (upper Copper R. = black solid, middle Copper R.=black dotted, lower Copper $\mathrm{R} .=$ solid gray, Chitina $\mathrm{R} .=$ dashed gray, and Bremner $\mathrm{R} .=$ black dashed). a The probability of an occupied nest being successful in relation to variation in both GDD and salmon abundance. b The relationship between GDD and the probability of an occupied nest being successful given salmon abundance is high $(+2 \mathrm{SD})$. c The relationship between salmon abundance and the probability of an occupied nest being successful given GDD is low $(-2 \mathrm{SD})$. d The relationship between the probability of a nest being highly successful, given that it is occupied and successful, and GDD and salmon abundance. Because covariates are scaled, the range of the $x$ axes covers +2SD and $-2 \mathrm{SD}$ for each covariate. Dashed vertical lines indicate 'average conditions'. Error bars are omitted for clarity

of positive impacts of temperature, our results suggest that although nest occupancy and success are depressed in years with warm weather in the spring and lower overall salmon run strength, the proportion of successful nests with two egg clutches tends to be higher.

While acknowledging differences in metrics, methodology, and survey coverage, our estimates of overall success and productivity over our 15-year study were similar to those based on past work in the area (Steidl et al. 1997). Our values were within the range of that suggested by Sprunt et al. (1973) for self-sustaining populations and consistency across time periods suggests that bald eagle populations are largely stable. Despite all outward evidence of population stability, we found that nest success increased gradually over time. These increases were accompanied by a concurrent increase in counts of migrating salmon passing the Miles Lake sonar site, which have approximately doubled since the late 1970s (Mejjati et al. 2010). The four largest runs on record (> 1.2 million salmon/year) occurred 2012-2015. Salmon are known to provide a nutrient subsidy in freshwater and terrestrial environments that can affect ecosystem productivity (Gende et al. 2002; Naiman et al. 2002; Schindler et al. 2003), and salmon carcasses serve as food resources for both adults and juvenile waterfowl (Gleason 2007) and are associated with higher invertebrate densities (Wipfli et al. 1998; Verspoor et al. 2011). As we learn more about this system, the role of marine-derived nutrients in supporting species at higher trophic levels may become more clear.

Evidence of the effects of weather and climate on wildlife populations includes mortality due to extreme events (e.g., Rattenbury et al. 2018), reduction in food resources (e.g., Rutz and Bijlsma 2006; Schmidt et al. 2018a, b), and phenological mismatches (Stenseth and Mysterud 2002; Durant et al. 2007; Post and Forchhammer 2007). Our findings further suggest that the effects of reductions in resource access can be nuanced and interconnected, thereby playing an important role in determining how variation in weather

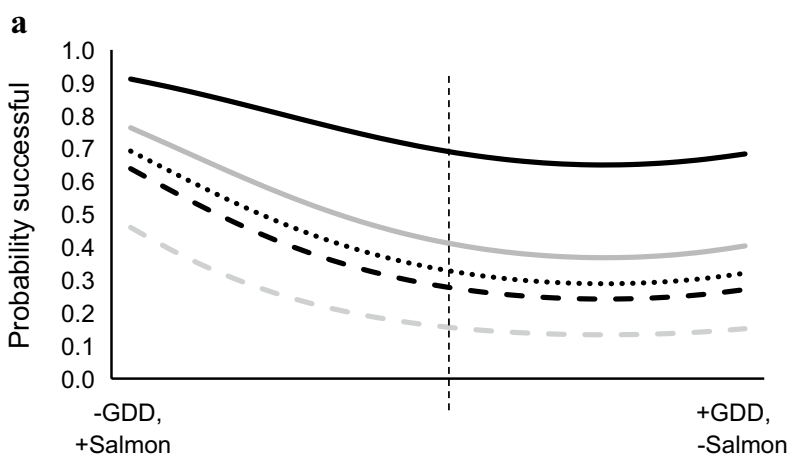

GDD and salmon conditions
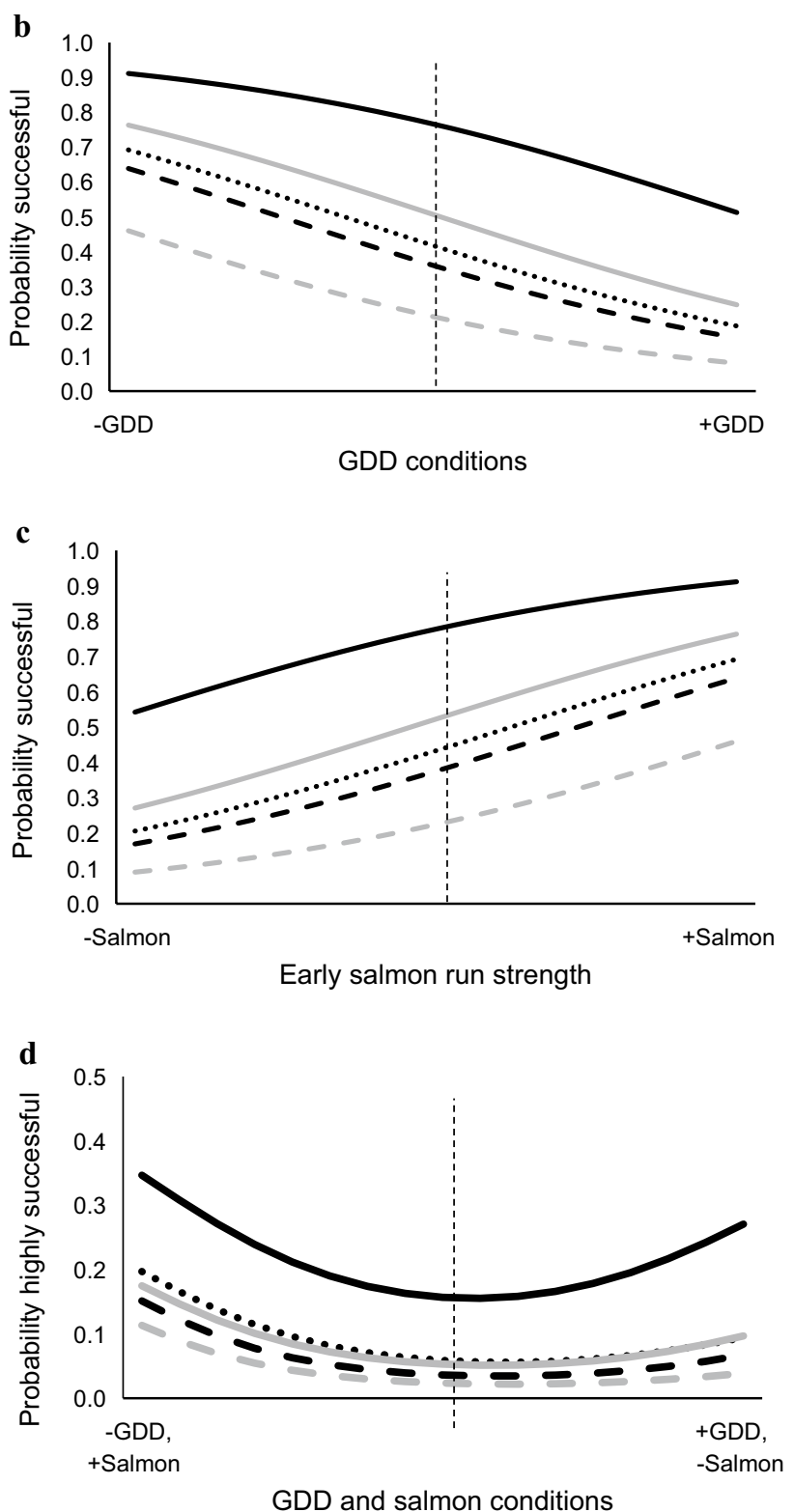

conditions can influence population dynamics. Although the effects of weather we describe may be unique to our glacially fed system, they contribute to our collective understanding 


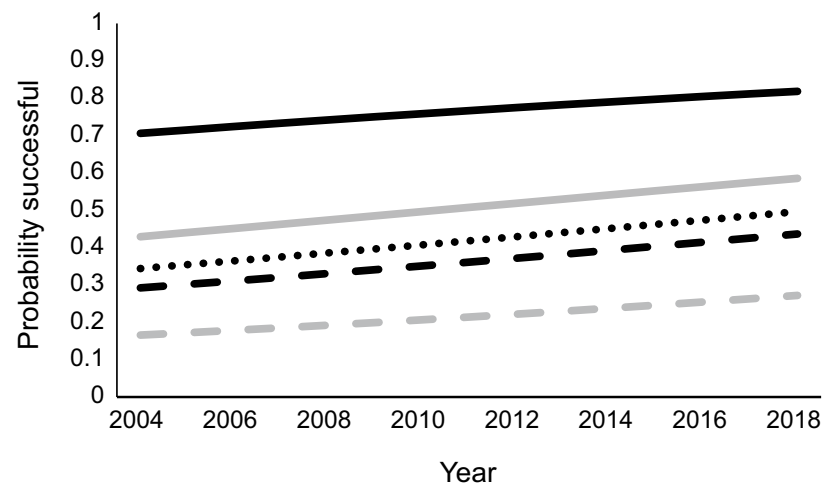

Fig. 3 Plot showing trend over time in the probability of success given a nest is occupied. GDD and salmon run strength covariates are held at mean values

of the importance of weather-induced changes in resource access (e.g., Korslund and Steen 2006; Stien et al. 2010; Arbeiter et al. 2016), which can play an important role in population dynamics. We expect that an improved mechanistic understanding of how resource abundance and availability influence populations will be important for predicting how a variety of ecosystems may respond to current and future climate change.

Acknowledgements We thank pilots T. Betts, L. Ellis, J. Lee, and M. Meekin for many hours of safe flight. M. Reid conducted initial surveys and C. Ketron conducted the 2018 survey. M. MacCluskie, C. McIntyre, B. Steidl, and 1 anonymous reviewer provided constructive comments on an earlier draft. Funding for this project was provided by the U.S. National Park Service through the Central Alaska Network and Wrangell-St. Elias National Park and Preserve. Any mention of trade or product names is for descriptive purposes only and does not imply endorsement by the U.S. government.

Author contribution statement JP collected the bald eagle data and JHS analyzed the data. All authors discussed the results and contributed to the development of the manuscript.

\section{References}

Anctil A, Franke A, Bety J (2014) Heavy rainfall increases nestling mortality of an arctic top predator: experimental evidence and long-term trend in peregrine falcons. Oecol 174:1033-1043

Anthony RG, Estes JA, Ricca MA, Miles AK, Forsman ED (2008) Bald eagles and sea otters in the Aleutian archipelago: indirect effects of trophic cascades. Ecology 89:2725-2735

Arbeiter S, Schulze M, Tamm P, Hahn S (2016) Strong cascading effect of weather conditions on prey availability and annual breeding performance in European bee-eaters Merops apiaster. J Ornithol 157:155-163

Bernatchez L, Dodson JJ (1987) Relationship between bioenergetics and behavior in anadromous fish migrations. Can J Fish Aquat Sci 44:399-407

Boelman NT, Krause JS, Sweet SK, Chmura HE, Perez JH, Gough L, Wingfield JC (2017) Extreme spring conditions in the Arctic delay spring phenology of long-distance migratory songbirds. Oecol 185:69-80

Brittingham MC, Temple SA (1988) Impacts of supplemental feeding on survival rates of black-capped chickadees. Ecology 69:581-589

Brooks SP, Gelman A (1998) General methods for monitoring convergence of iterative simulations. J Comput Graph Stat 7:434-455

Buehler DA (2000) Bald eagle (Haliaeetus leucocephalus), version 20. In: Poole AF, Gill FB (eds) The birds of North America. Cornell Lab of Ornithology, Ithaca. https://doi.org/10.2173/bna.506

Byholm P, Nikula A, Kentta J, Taivalmaki J-P (2007) Interactions between habitat heterogeneity and food affect reproductive output in a top predator. J Anim Ecol 76:392-401

Cruz J, Windels SK, Thogmartin WE, Crimmins SM, Grim LH, Zuckerberg B (2018) Managing individual nests promotes population recovery of a top predator. J Appl Ecol 55:1418-1429

Durant JM, Hjermann DØ, Ottersen G, Stenseth NC (2007) Climate and the match or mismatch between predator requirements and resource availability. Clim Res 33:271-283

Dybala KE, Eadie JM, Gardali T, Seavy NE, Herzog MP (2013) Projecting demographic responses to climate change: adult and juvenile survival respond differently to direct and indirect effects of weather in a passerine population. Glob Change Biol 19:2688-2697

Elliot JE, Moul IE, Cheng KM (1998) Variable reproductive success of bald eagles on the British Columbio coast. J Wildl Manag 62:518-529

Elliott KH, Elliott JE, Wilson LK, Jones I, Stenerson K (2011) Densitydependence in the survival and reproduction of bald eagles: linkages to chum salmon. J Wildl Manag 75:1688-1699

Fairhurst GD, Bechard MJ (2005) Relationships between winter and spring weather and northern goshawk (Accipiter gentilis) reproduction in northern Nevada. J Raptor Res 39:229-236

Farley EV, Starovotov A, Naydenko S, Heintz R, Trudel M, Guthrie C, Eisner L, Guyon JR (2011) Implications of a warming eastern Bering Sea for Bristol Bay sockeye salmon. ICES J Mar Sci 68:1138-1146

Finney BP, Gregory-Eaves I, Sweetman J, Douglas MSV, Smol JP (2000) Impacts of climate change and fishing on Pacific salmon abundance over the past 300 years. Science 290:795-799

Franklin AB, Anderson DR, Gutierrez RJ, Burnham KP (2000) Climate, habitat quality, and fitness in northern spotted owl populations in northwestern California. Ecol Monogr 70:539-590

Frederiksen M, Edwards M, Richardson AJ, Halliday NC, Wanless $S$ (2006) From plankton to top predators: bottom-up control of a marine food web across four trophic levels. J Anim Ecol 75:1259-1268

Gende SM, Willson MF (1997) Supplemental feeding experiments of nesting bald eagles in southeastern Alaska. J Field Ornithol 68:590-601

Gende SM, Willson MF, Jacobsen M (1997) Reproductive success of bald eagles (Haliaeetus leucocephalus) and its association with habitat or landscape features and weather in southeast Alaska. Can J Zool 75:1595-1604

Gende SM, Edwards RT, Willson MF, Wipfli MS (2002) Pacific salmon in aquatic and terrestrial ecosystems: Pacific salmon subsidize freshwater and terrestrial ecosystems through several pathways, which generates unique management and conservation issues but also provides valuable research opportunities. BioSci 52:917-928

Gende SM, Quinn TP, Willson MF, Heintz R, Scott TM (2004) Magnitude and fate of salmon-derived nutrients and energy in a coastal stream ecosystem. J Freshw Ecol 19:149-160

Gill VA, Hatch SA, Lanctot RB (2002) Sensitivity of breeding parameters to food supply in black-legged kittiwakes Rissa tridactyla. Ibis $144: 268-283$

Gleason JS (2007) Mallards feeding on salmon carcasses in Alaska. Wilson J Ornithol 119:105-107 
Glenn EM, Anthony RG, Forsman ED (2010) Population trends in northern spotted owls: associations with climate in the Pacific Northwest. Biol Cons 143:2543-2552

Hansen AJ (1987) Regulation of bald eagle reproductive rates in southeast Alaska. Ecology 68:1387-1392

Harvey CJ, Moriarty PE, Salathé EP Jr (2012) Modeling climate change impacts on overwintering bald eagles. Ecol Evol 2:501-514

Helfield JM, Naiman RJ (2006) Keystone interactions: Salmon and bear in riparian forests of Alaska. Ecosystems 9:167-180

Hilderbrand GV, Farley SD, Schwartz CC, Robbins CT (2004) Importance of salmon to wildlife: implications for integrated management. Ursus 15:1-9

Hinch SG, Rand PS (1998) Swim speeds and energy use of uprivermigrating sockeye salmon (Oncorhynchus nerka): role of local environment. Can J Fish Aquat Sci 55:1821-1831

Hodgson S, Quinn TP, Hilborn R, Francis RC, Rogers DE (2006) Marine and freshwater climatic factors affecting interannual variation in the timing of return migration to fresh water of sockeye salmon (Oncorhynchus nerka). Fish Oceanogr 15:1-24

Hoff MH, Meyer MW, Stappen JV, Fratt TW (2004) Relationships between bald eagle productivity and dynamics of fish populations and fisheries in the Wisconsin waters of Lake Superior, 1983-1999. J Great Lakes Res 30:434-442

Keefer ML, Peery CA, Caudill CC (2007) Migration timing of Columbia River spring chinook salmon: effects of temperature, river discharge, and ocean environment. Trans Am Fish Soc 137:1120-1133

Kéry M, Schaub M (2012) Bayesian population analysis using WinBUGS: a hierarchical perspective. Academic Press, San Diego

Korpimaki E (1992) Fluctuating food abundance determines the lifetime reproductive success of male Tengmalm's owls. J Anim Ecol 61:103-111

Korslund L, Steen H (2006) Small rodent winter survival: snow conditions limit access to food resources. J Anim Ecol 75:156-166

Kozie K (1996) Bald eagle productivity for Wrangell-St. Elias National Park and Preserve 1993-1996. National Park Service Report. 17 pp. https://irma.nps.gov/DataStore/DownloadFile/528353. Accessed 17 Dec 2019

MacKenzie DI, Nichols JD, Hines JE, Knutson MG, Franklin AB (2003) Estimating site occupancy, colonization, and local extinction when a species is detected imperfectly. Ecology 84:2200-2207

MacKenzie DI, Seamans ME, Gutierrez RJ, Nichols JD (2012) Investigating the population dynamics of California spotted owls without marked individuals. J Ornithol 152:597-604

MacKenzie DI, Nichols JD, Royle JA, Pollock KH, Bailey LL, Hines JE (2018) Occupancy estimation and modeling: inferring patterns and dynamics of species occurrence, 2nd edn. Academic Press, San Diego

Martin J, McIntyre CL, Hines JE, Nichols JD, Schmutz JA, MacCluskie MC (2009) Dynamic multistate site occupancy models to evaluate hypotheses relevant to conservation of golden eagles in Denali National Park, Alaska. Biol Cons 142:2723-2731

Martins EG, Hinch SG, Cooke SJ, Patterson DA (2012) Climate effects on growth, phenology, and survival of sockeye salmon (Oncorhynchus nerka): a synthesis of the current state of knowledge and future research directions. Rev Fish Biol Fisher 22:887-914

McIntyre CL, Schmidt JH (2012) Ecological and environmental correlates of territory occupancy and breeding performance of migratory golden eagles Aquila chrysaetos in interior Alaska. Ibis 154:124-135

Mejjait SE, Bell J, Botz J, Faulkner A, Maxwell S (2010) Using hydroacoustic methods to enumerate migrating salmon in the Copper River, Miles Lake sonar project, 2007. Alaska Department of Fish and Game, Fishery Data Report 10-98, Anchorage, Alaska, USA
Mizel JD, McIntyre CL, Lewis SB, Lindberg MS, Schmidt JH (2018) A multi-state, time-removal model for population dynamics of cliff-nesting raptors. J Wildl Manag 82:1701-1710

Mougeot F, Gerrard J, Dzus E, Arroyo B, Gerrard PN, Dzus C, Bortolotti G (2013) Population trends and reproduction of bald eagles at Besnard Lake, Saskatchewan, Canada 1968-2012. J Raptor Res 47:96-107

Mueter FJ, Peterman RM, Pyper BJ (2002) Opposite effects of ocean temperature on survival rates of 120 stocks of Pacific salmon (Oncorhyncus spp.) in northern and southern areas. Can J Fish Aquat Sci 59:456-463

Naiman RJ, Bilby RE, Schindler DE, Helfield JM (2002) Pacific salmon, nutrients, and the dynamics of freshwater and riparian ecosystems. Ecosystems 5:399-417

Nichols JD, Hines JE, MacKenzie DI, Seamans ME, Gutierrez RJ (2007) Occupancy estimation and modeling with multiple states and state uncertainty. Ecology 88:1395-1400

Parker KL, Barboza PS, Gillingham MP (2009) Nutrition integrates environmental responses of ungulates. Funct Ecol 23:57-69

Parmesan C, Root TL, Willig MR (2000) Impacts of extreme weather and climate on terrestrial biota. Bull Am Meteorol Soc $81: 443-450$

Post E, Forchhammer MC (2007) Climate change reduces reproductive success of an Arctic herbivore through trophic mismatch. Philos Trans Royal Soc B 363:2369-2375

Post E, Stenseth NC (1999) Climatic variability, plant phenology, and northern ungulates. Ecology 80:1322-1339

Preston KL, Rotenberry JT (2006) Independent effects of food and predator-mediated processes on annual fecundity in a songbird. Ecology 87:160-168

R Development Core Team (2014) R: a language and environment for statistical computing. R. Foundation for Statistical Computing, Vienna, Austria. http://www.R-project.org/. Accessed 17 Dec 2019

Rand PS, Hinch SG, Morrison J, Foreman MGG, MacNutt MJ, Macdonald JS, Healey MC, Farrell AP, Higgs DA (2006) Effects of river discharge, temperature, and future climates on energetics and mortality of adult migrating Fraser River sockeye salmon. Trans Am Fish Soc 135:655-667

Rattenbury KL, Schmidt JH, Swanson DK, Borg BL, Mangipane BA, Sousanes PJ (2018) Delayed spring onset drives declines in abundance and recruitment in a mountain ungulate. Ecosphere 9:e02513

Redpath SM, Arroyo BE, Etheridge B, Leckie F, Bouwman K, Thirgood SJ (2002) Temperature and hen harrier productivity: from local mechanisms to geographical patterns. Ecography 25:533-540

Ritchie RJ, Ambrose S (1996) Distribution and population status of bald eagles (Haliaeetus leucocephalus) in interior Alaska. Arctic 49:120-128

Rodríguez C, Bustamante J (2003) The effect of weather on lesser kestrel breeding success: can climate change explain historical population declines? J Anim Ecol 72:793-810

Rubenstein MA, Christophersen R, Ransom JI (2019) Trophic implications of a phenological paradigm shift: bald eagles and salmon in a changing climate. J Appl Ecol 56:769-778

Rutz C, Bijlsma RG (2006) Food-limitation in a generalist predator. Proc Royal Soc B 273:2069-2076

Schindler DE, Scheuerell MD, Moore JW, Gende SM, Francis TB, Palen WJ (2003) Pacific salmon and the ecology of coastal ecosystems. Front Ecol Environ 1:31-37

Schmidt JH, McIntyre CL, Roland CA, MacCluskie MC, Flamme MJ (2018a) Bottom-up processes drive reproductive success in an apex predator. Ecol Evol 8:1833-1841

Schmidt JH, Rexstad EA, Roland CA, McIntyre CL, MacCluskie MC, Flamme MJ (2018b) Weather-driven change in primary 
productivity explains variation in the amplitude of two herbivore population cycles in a boreal system. Oecol 186:435-446

Sergio F, Newton I (2003) Occupancy as a measure of territory quality. J Anim Ecol 72:857-865

Shulski M, Wendler G (2007) The climate of Alaska. University of Alaska Press, Fairbanks, p 216

Sillett TS, Holmes RT, Sherry TW (2000) Impacts of a global climate cycle on population dynamics of a migratory songbird. Science 288:2040-2042

Sprunt A IV, Robertson WB Jr, Postupalsky S, Hensel RJ, Knoder CE, Ligas FJ (1973) Comparative productivity of six bald eagle populations. Trans North Am Wildl Nat Resour Conf 38:96-106

Stalmaster MV, Gesssaman JA (1984) Ecological energetic and foraging behavior of overwintering bald eagles. Ecol Monog 54:407-428

Steidl RJ, Kozie KD, Anthony RG (1997) Reproductive success of bald eagles in interior Alaska. J Wildl Manag 61:1313-1321

Stenseth NC, Mysterud A (2002) Climate, changing phenology, and other life history traits: nonlinearity and match-mismatch to the environment. Proc Nat Acad Sci 99:13379-13381

Stien A, Loe LE, Mysterud A, Severinsen T, Kohler J, Langvatn R (2010) Icing events trigger range displacement in a high-arctic ungulate. Ecology 91:915-920

Swenson JE, Alt KL, Eng RL (1986) Ecology of bald eagles in the Greater Yellowstone Ecosystem. Wildlife Monogr 95:3-46

Thomas A, O’Hara B, Ligges U, Sturtz S (2006) Making BUGS Open. R News 6:12-17

Thompson PM, Ollason JC (2001) Lagged effects of ocean climate change on fulmar population dynamics. Nature 413:417-420

Väli Ü (2012) Factors limiting reproductive performance and nestling sex ratio in the Lesser Spotted Eagle Aquila pomarina at the northern limit of its range: the impact of weather and prey abundance. Acta Ornithol 47:157-168

Verspoor JJ, Braun DC, Stubbs MM, Reynolds JD (2011) Persistent ecological effects of a salmon-derived nutrient pulse on stream invertebrate communities. Ecosphere 2:1-17

Wallach AD, Izahaki I, Toms JD, Ripple WJ, Shanas U (2015) What is an apex predator? Oikos 124:1453-1461

Watts BD, Duerr AE (2010) Nest turnover rates and list-frame decay in bald eagles: implications for the national monitoring plan. $\mathrm{J}$ Wildl Manag 74:940-944

White TCR (2008) The role of food, weather, and climate in limiting the abundance of animals. Biol Rev 83:227-248

Wiehn J, Korpimaki E (1997) Food limitation on brood size: experimental evidence in the Eurasian kestrel. Ecology 78:2043-2050

Wilson TL, Schmidt JH, Thompson WL, Phillips LM (2014) Using double-observer aerial surveys to monitor nesting bald eagles in Alaska: are all nests available for detection? J Wildl Manag 78:1096-1103

Wilson TL, Phillips LM, Mangipane BA (2017) Improving bald eagle nest monitoring with a second spring survey. J Wildl Manag 81:545-551

Wilson TL, Schmidt JH, Mangipane BA, Kolstrom R, Bartz KK (2018) Nest use dynamics of an undisturbed population of bald eagles. Ecol Evol 8:7346-7354

Wipfli MS, Hudson J, Caouette J (1998) Influence of salmon carcasses on stream productivity: response of biofilm and benthic macroinvertebrates in southeastern Alaska, USA. Can J Fish Aquat Sci 55:1503-1511

Zwiefelhofer D (2007) Comparison of bald eagle (Haliaeetus leucocephalus) nesting and productivity at Kodiak National Wildlife Refuge, Alaska, 1963-2002. J Raptor Res 41:1-9 